\title{
Bulletin of Tibetology
}

\section{CULTURAL HERITAGE OF SIKKIM}

-Mrs Talat Saeed

Among high mountain ranges of Eastem Himalavas, where I stand today is a beautiful region. cmbroidered with lush green jungles of flowering plants and trees dotted with rippling streams of glittering rivers and magnificent high mountains studded with sparkling snow, ice slopes and glaciers where yeti and shippi prowl.

This 22 nd state of India is guarded by virgin deity Khan-chen dzonga which is the third highest peak of the world.

Sikkim is Himalayan state and its society is the Himalayan society with many social traits. The ancient history of this Himalayan region still lies in obscurity. All that we know about pre-historic period is through legends and myths which have not been authenticated by historians

Some anthropologists say Sikkim was inhabited in pre-historic times by three tribes NaongChang and the Mon (Pcople of India). The Lepcha who entered Sikkim sometimes later absorbed them completely: So the origin of Lepchas is shrouded in mystery but it seems that they belong to the clan of Nagas who lived in south of Brahmaputra valley.

Lepchas, the children of nature were very shy, simple, peace loving and deeply religious people. They worshipped nature and the spirits of nature, they were originally animists. Upto the end of 14th century, there was no social organisation in Sikkim. Credit goes to person called Tur-ve-pa-no for organizing Sikkimese into a society. He was an elected leader or temporal king. In A.D. 1400 he was killed in a battle with some Nepali tribe and was succeeded by three kings of his own lineage. The monarchy came to an end with the death of the 3rd king. By now Lepchas had learnt to elect their leaders for scttling crucial persons were considered as temporal and spiritual leaders, they worked as men of medicine and magic too.

Historians say the history of Sikkim began with the king Indrabhuti who ruled Himachal. $A$ prince who migrated due to certain reasons towards the eastern Himalayas is said to have founded the Minyak kingdom in eastern Tibet, some where in the ninth century A.D. A legendary prince of this Minyak dynasty 25 th in lineage came to Sikkim while he was on pilgrimage. This vencrable prince was given a title of Khye Bumsa (means one who possesses the strength of one lakh persons) for his legendary work did at Khabe for Sakya monastery. He was also given the hand of Sakya Chief's daughter in marriage. According to records he was insisted upon to settle down there. He accepted the offer and settled down with his wife at Phari in Chumbhi valley. Later a Lepcha Chief blessed Khya-Bumsa for sons, he also prophesied that his descendants would one day reign over all Sikkim.

Phuntsog Namgyal was one of Khya-Bumsa descendants. Historians say Phuntsog Namgyal was bom at Gangtok in 1614. According to the prophecy of Guru Padmasambhava he was given the honour of temporal and religious head. by three Lamas who entered Sikkin from different directions at Yoksam. He was given the title of Chogyal and received recognition from Dalai Lama of Tibet.

This dynasty ruled over Sikkim for about 332 years. Phunstog Namgyal proved to be ver 


\section{Bulletin of Tibetology}

efficient, legendary and capable administrator. He declared Mahayana Buddhism as the state religion. He very tactfully kept the Lepchas, Bhutias and Limbus together.

This period of 332 years of Namgyals is remarkable. Many reforms were donc. Clans. tribes and districts were organized. Orders were given that the second of the three sons of Bhutia family must be ordained a monk of the monastery which was also open to the Tsong community. Sacred places were patronized, religious dances were adopted to keep alive the martial and native tradition,

Many monasteries were built. Matrimonial alliances between Bhutias and Lepchas were accepted, alphabet of Lepcha language was invented. Many social and economic reforms were initiated, such as public gambling, Jharlongi, or forced unpaid labour, landlord's personal police and their courts were abolished. The lease system was dropped and peasant were asked to make direct payments of the tax to the state. Formal education was introduced. schools were opened, Cottage industries were established. Sikkim was slowly and gradually advancing on the path of planned and aimed economic development during this dynasty.

In the early twentieth century Sikkimese soldiers came back after the World War II with the awareness of freedom and they wanted complete abolition of landlordism. After the transfer of power to India. where India became an independent democracy they started to focus their wide open eyes towards it and demanded a complete union with India. Finally Sikkim merged with India on 26th of April, 1975.

There are three types of monasteries in Sikkim. Rock caves where saints worshipped. Gompas where Lamas meditate. Monasteries of village and towns are the places of religious discourses worship and meditation. They are the places where religious books. manuscripts and murals are kept.

Sikkim is rich in its festivities almost one or two festivals are celebrated every two months. Two of the Sikkimese festivals are of most importance, held in the honour of Guru Rinpoche and other for protecting deity Kanchendzonga.

Hindus of Sikkim observe the great festivals of Dassehra. Durga Puja and Makar Sankrati. Ids and Moharram are celebrated by Muslims of Sikkim and Christmas by Christians.

In this Himalayan society there is considerable relaxation in terms of exchange of food and water across communities. Most of the communities accept food both Kachcha and Pucca and water. Inter community marriage are reported from seventeen communities. There is much higher participation in festivals.

People of Sikkim are caring and feel responsibility towards their families. fellowmen and community.

So this is the land of mixed culture represented by Lepchas, Bhutias and Nepalese. 